\title{
Study the Effect of Cold Water Extracts of Petroselinum crispum Leaves on Culex pipiens Instars
}

\author{
May Hameed Mohammad AL-Dehamee \\ College of Environmental Science, Al-Qasim Green University,Babil , Iraq \\ mayhameed85@yahoo.com
}

Submission date:- 18/4/2018 Acceptance date:- 26/3/2018 Publication date:- 16/10/2018

Keywords: Extracts, Parsley, Mosquitoes, $\mathrm{LC}_{50}$, Instars.

\begin{abstract}
This study aimed to know the effect of different concentrations of cold water extract of Petroselinum crispum leaves on Culex pipiens instars and find the half lethal concentration $\left(\mathrm{LC}_{50}\right)$. The results showed that the third instar of $C$. pipiens were more effective by cold water extract than first, second, and fourth instar after 24 hours from exposure to different concentrations $(250,300,350,400) \mathrm{mg} / \mathrm{l}$. Results appeared that the percentage of mortalities after 24 hours from exposure to cold water extracts were $(37,44,67,85) \%,(26,41,67,78) \%,(42,65$, $77,92) \%$ and $(16,32,52,89) \%$ with $\operatorname{LC}_{50}(300),(319),(267)$ and $(333) \mathrm{mg} / \mathrm{l}$ for first, second, third, and fourth instar of $C$. pipiens respectively. Also, the results didn't show a significant differentiation in level of probability 0.05 , but appeared positive correlation coefficient between the percentage of mortalities and the concentrations, and negative correlation coefficient between the percentage of survival and the concentrations.
\end{abstract}

\section{1-Introduction}

Many studies try to find the natural compounds working as insecticides to many insects especially mosquitoes and didn't cause death to many life forms and serve the economy. As well as they could be unharmed on environment and effective on target when they used on water environment and with lower rate of pollution and highly degradation with fewer non-target organisms [1]. For that many researchers were digging to find these compounds in plants and in few cases in animals.

Parsely plant (Petroselinum crispum) is a member of the family of Umbelliferae (Apiaceae) which is the same family of celery, natively from Mediterranean region and cultivated in many various parts of the world [2]. It's a herb that has compound leaves and clustered white flowers in groups with umbrella shape fruit compound. Parsley has aromatic odor and shining green leaves which have high chlorophyll and rich with vitamins such as vitamin C and minerals such as iodine, iron, and others [3].

Mosquitoes belong to the family Culicidae and the order Diptera. They are the most important arthropod vectors that caused human and animals' diseases and can be found in all tropical and subtropical countries [4]. The Culex pipiens is a species which belongs to subfamily of Culicinae where the instars hanging down under the water surface by their siphon [1].

The study aimed to find the possibility of using cold water extract of leaves of parsely plant $P$. crispum to control instars of $C$. pipiens mosquitoes by using four stages of instar (first and fourth instar) that can be growth and development to adult in aquatic environment and find if possible $\mathrm{LC}_{50}$ for each instar after exposure to different concentrations of extract.

\section{2-Materials and methods}

\subsection{Breeding of insect}

Similar method of [5] and way of [6] have been used. The egg rafts of $C$. pipiens mosquitoes have been collected from some pools of standing drainage water in the Province of Babylon and transformed to the laboratory in a plastic glass filled with water during the period from 1-7-2017 to 1-2-2018. The egg rafts transformed to the beaker that filled with water waiting to hatch. After that the diet which is composed of yeast and bran flour has been added. 
The instars of $C$. pipiens have been collected and breaded at $28 \pm 1 \mathrm{C}^{0}$ temperature as possible as could. The insect has been diagnosed in natural history museum in Baghdad University. To prepare for these studies, 30 instars from each instar has been taken to the plastic glass filled with $100 \mathrm{ml}$ from each concentration in three replications with food.

\subsection{Preparation of extracts}

Similar method of [7] and the way followed by [8] have been used. The parsley leaves have been collected and washed with fresh tap water then dried for 24 hours at a temperature of room. After that it has been grinded by electrical mill and sieved through clean passage gauze to remove the parts that didn't grind well. The weight of 500 gm from preparing powder has been taken and mixed with $750 \mathrm{ml}$ cold distilled water. The sample was mixed well by an electric mixer until contents seem to be identical. The contents separated by normal filter papers and then by centrifuge on speed of $3000 \mathrm{r} / \mathrm{min}$ for 15 minutes to have the fluid filtrate. These fluids have been left to dry in room temperature for getting a vegetable powder. To prepare $2.5 \%$ concentration from extract as stock; $2.5 \mathrm{gm}$ from vegetable powder for extract has been mixed with $100 \mathrm{ml}$ of distilled water to prepare $(250,300,350,400)$ $\mathrm{mg} / \mathrm{l}$ concentrations. Finally, the aqueous extract transferred to bottles under refrigeration until the test.

\section{3- Calculate the $\mathrm{LC}_{50}$}

To study the effect of cold water extracts of $P$. crispum leaves on $C$. pipiens instars; the $\mathrm{LC}_{50}$ has been found after using series of concentrations (250-400) $\mathrm{mg} / \mathrm{l}$ in addition to the control sample. The young $C$. pipiens (age less than 24 hours) in average of 30 instars have been added to container $250 \mathrm{ml}$ that have $100 \mathrm{ml}$ of different concentration from extract in three replicators. The percentage of mortalities and the value of $\mathrm{LC}_{50}$ have been calculated after 24 hours as a cute exposure by using the equation of straight line $[Y=b x+a(a=i n t e r c e p t, b=$ slope)] [6]. The data before that corrected with Abbott equation [9].

\section{4- Experimental design and statistical analysis}

A completely randomized design (CRD) was used. Data was analyzed statistically by using less significant differences (LSD) at 0.05 after subjection to the analysis of variance [10].

\section{5-RESULTS AND DISCUSSION}

The results in Table (1) showed Average survival and percentage of mortalities of $C$. pipiens instars after exposure to different concentration of cold water extracts of $P$. crispum leaves. Which the percentage of mortalities was (37-85) \%, (26-78) \%, (42-92) \% and (16-89) \% to first, second, third and fourth instar of instars respectively. The results didn't show a significant differentiation but they appeared positive correlation coefficient where the percentage of mortalities increased with increasing concentration. These percentage of mortalities could be returned to content parsley leaves components that have toxic properties on some species of organisms such as flavonoids, coumarins, and terpenes [11], or have compounds that have variety toxic properties on respiratory and digestive system of insects [12] that increased in water extract with increasing concentration. Another study pointed to find some aromatic and aliphatic compounds that derived from phenols could be soluble in water and worked as active eliminator insects [13].

The results in Table (1) and Figure $(1,2,3)$ pointed to have first instar of $C$. pipiens high percentage of mortalities (37-85) \% in average survival (17-4) (instar/30 instars) with lower $\mathrm{LC}_{50}$ value (300) $\mathrm{mg} / \mathrm{l}$, as a result for uncompleted cuticle of instar body [14] that makes it also sensitive to the chemical that found in extract. Also, it showed that the second instar of C. pipiens has low $\mathrm{LC}_{50}$ value (319) $\mathrm{mg} / \mathrm{l}$ than fourth instar that has $\mathrm{LC}_{50}$ value (333) $\mathrm{mg} / \mathrm{l}$. This means that second instar of $C$. pipiens was more sensitive to cold water extract than fourth instar. This state could be because of lower activity of fourth instar of $C$. pipiens as a reason for initiation of internal changes to pupa [15] where the biological activities in lower limits. For that there were some studies referred to fourth instar of $C$. pipiens as semi-dweller instar where the feeding has begun stop [16].

Also, the results in Table (1) and Figure (3) showed that third instar of $C$. pipiens was most effective by cold water extract than another instars, where the percentage of mortalities was (42-92) \% in average survival (15-2) (instar/30 instars) and has lower value of $\mathrm{LC}_{50}(267) \mathrm{mg} / \mathrm{l}$ than another instars. These results could be return to the higher biological activity of third instar of $C$. pipiens for preparing to convert to the fourth instar of $C$. pipiens that have less activity as a result to prepared to convert to pupa [17]. This situation makes third instar of $C$. pipiens more effective by soluble oxalate that found in extract because of high metabolic rate [3]. Some studies referred to have third instar of $C$. pipiens higher level of metabolism than first, second and fourth instar as a result to begin serial radical changes on the level of cell differentiation that makes third instar more sensitivity to different chemicals than other instars [18].

Results in Table (1) Figure (4) appeared percentage of survival instars in different concentration of cold water extract, which were $(63-15) \%,(74-22) \%,(58-8) \%$ and (84-11) \% for first, second, third and fourth instar of $C$. pipiens respectively. The results didn't appear a significant differentiation but showed that the percentage of survival decreased with increasing concentration with negative correlation coefficient. The percentage of survival could be due to the presence of a significant individual differentiation among individuals of different instars of $C$. pipiens mosquitoes. Many studies referred to these differentiation as caused by variety of mutations that could be happened in fertilized eggs before hatching [19]. Sometimes and because of conditions that made these mutations the hatching instars should be have mutant with resistant gene [20], or mutant with sensitive gene [21] to the chemicals. 


\section{6- Conclusions}

This study showed that the third instar of $C$. pipiens mosquitoes were more effective by cold water extract of Petroselinum crispum leaves than first, second, and fourth instar after 24 hours from exposure to different concentrations $(250,300,350,400) \mathrm{mg} / \mathrm{l}$. and the percentage of instars mortalities increases with increasing concentrations.

Table (1) Average survival and mortalities, and percentage of survival and mortalities of $C$. pipiens instars after 24 hours exposure to different concentration of cold water extract of $P$. crispum leaves.

$(\mathrm{LSD}=$ not found in results)

\begin{tabular}{|c|c|c|c|c|}
\hline \multicolumn{5}{|c|}{ First Instar } \\
\hline concentration & $\begin{array}{c}\text { Average of } \\
\text { survival }\end{array}$ & $\begin{array}{l}\text { Average of } \\
\text { mortalities }\end{array}$ & $\begin{array}{c}\text { Percentage of } \\
\text { survival }\end{array}$ & $\begin{array}{c}\text { Percentage of } \\
\text { mortalities }\end{array}$ \\
\hline Control & 27 & 3 & 90 & 10 \\
\hline 250 & 17 & 10 & 63 & 37 \\
\hline 300 & 15 & 12 & 56 & 44 \\
\hline 350 & 9 & 18 & 33 & 67 \\
\hline 400 & 4 & 24 & 15 & 85 \\
\hline \multicolumn{5}{|c|}{ Second instar } \\
\hline concentration & $\begin{array}{c}\text { Average of } \\
\text { survival }\end{array}$ & $\begin{array}{l}\text { Average of } \\
\text { mortalities }\end{array}$ & $\begin{array}{c}\text { Percentage of } \\
\text { survival }\end{array}$ & $\begin{array}{c}\text { Percentage of } \\
\text { mortalities }\end{array}$ \\
\hline Control & 27 & 3 & 90 & 10 \\
\hline 250 & 20 & 7 & 74 & 26 \\
\hline 300 & 16 & 11 & 59 & 41 \\
\hline 350 & 9 & 18 & 33 & 67 \\
\hline 400 & 6 & 21 & 22 & 78 \\
\hline \multicolumn{5}{|c|}{ Third instar } \\
\hline concentration & $\begin{array}{c}\text { Average of } \\
\text { survival }\end{array}$ & $\begin{array}{l}\text { Average of } \\
\text { mortalities }\end{array}$ & $\begin{array}{c}\text { Percentage of } \\
\text { survival }\end{array}$ & $\begin{array}{c}\text { Percentage of } \\
\text { mortalities }\end{array}$ \\
\hline Control & 26 & 4 & 87 & 13 \\
\hline 250 & 15 & 11 & 58 & 42 \\
\hline 300 & 9 & 17 & 35 & 65 \\
\hline 350 & 6 & 20 & 23 & 77 \\
\hline 400 & 2 & 24 & 8 & 92 \\
\hline \multicolumn{5}{|c|}{ Fourth instar } \\
\hline concentration & $\begin{array}{c}\text { Average of } \\
\text { survival }\end{array}$ & $\begin{array}{l}\text { Average of } \\
\text { mortalities }\end{array}$ & $\begin{array}{c}\text { Percentage of } \\
\text { survival }\end{array}$ & $\begin{array}{c}\text { Percentage of } \\
\text { mortalities }\end{array}$ \\
\hline Control & 25 & 5 & 83 & 17 \\
\hline 250 & 21 & 4 & 84 & 16 \\
\hline 300 & 17 & 8 & 68 & 32 \\
\hline 350 & 12 & 13 & 48 & 52 \\
\hline 400 & 3 & 22 & 11 & 89 \\
\hline
\end{tabular}




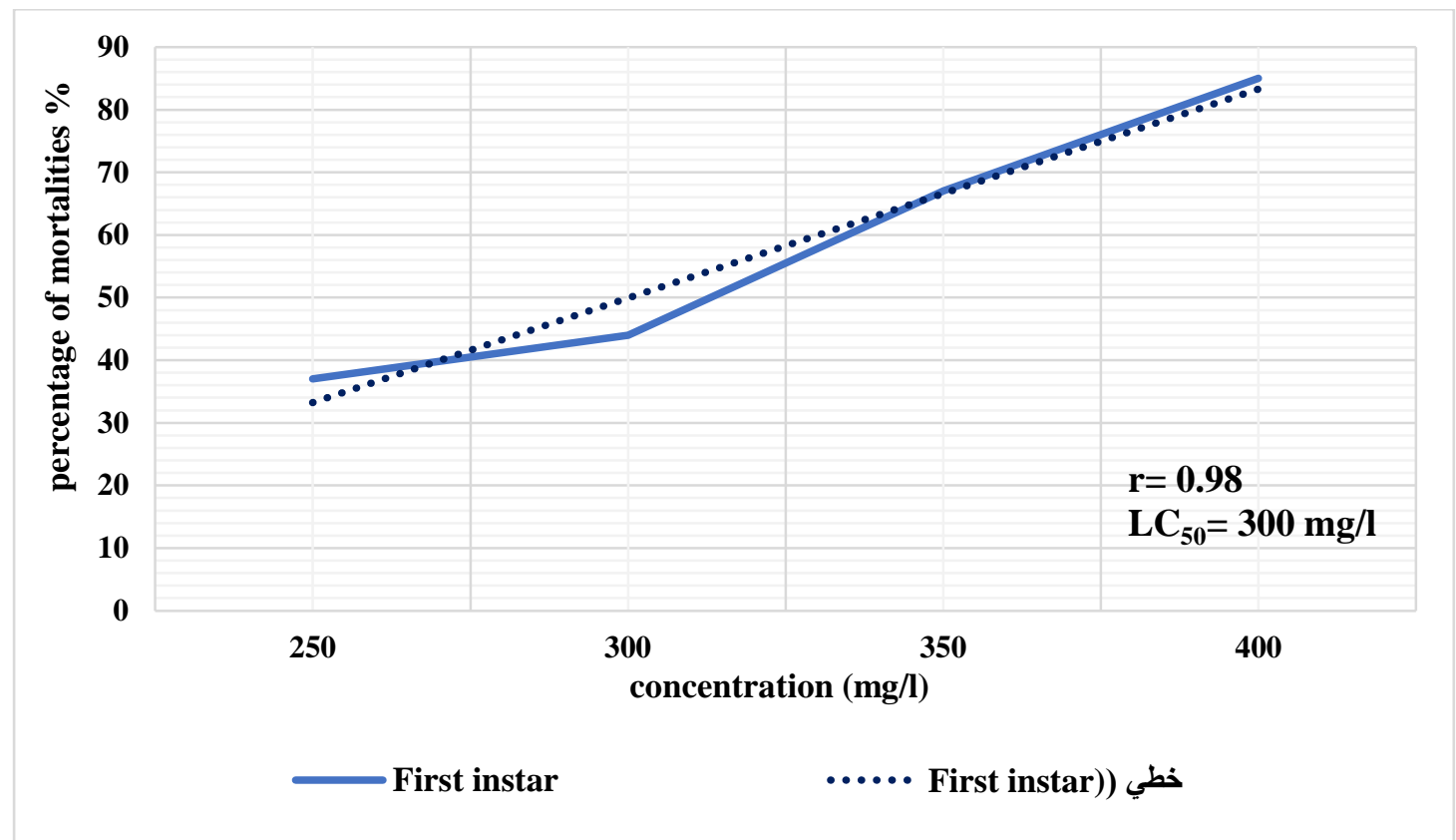

Figure (1) $\mathrm{LC}_{50}$ value for first instar of $C$. pipiens after 24 hours exposure to different concentration of cold water extract of $P$. crispum leaves.

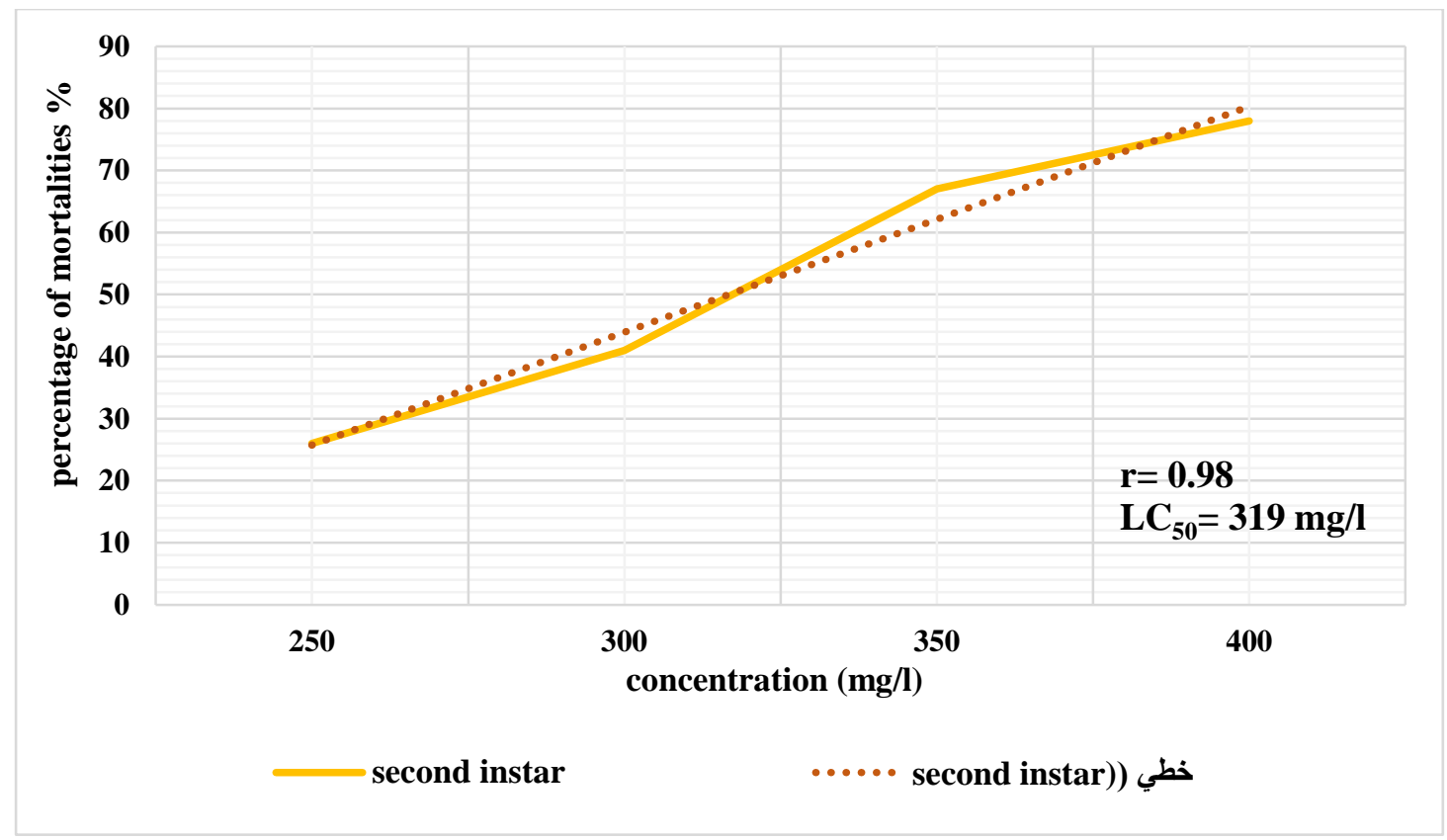

Figure (2) $\mathrm{LC}_{50}$ value for second instar of $C$. pipiens after 24 hours exposure to different concentration of cold water extract of $P$. crispum leaves. 


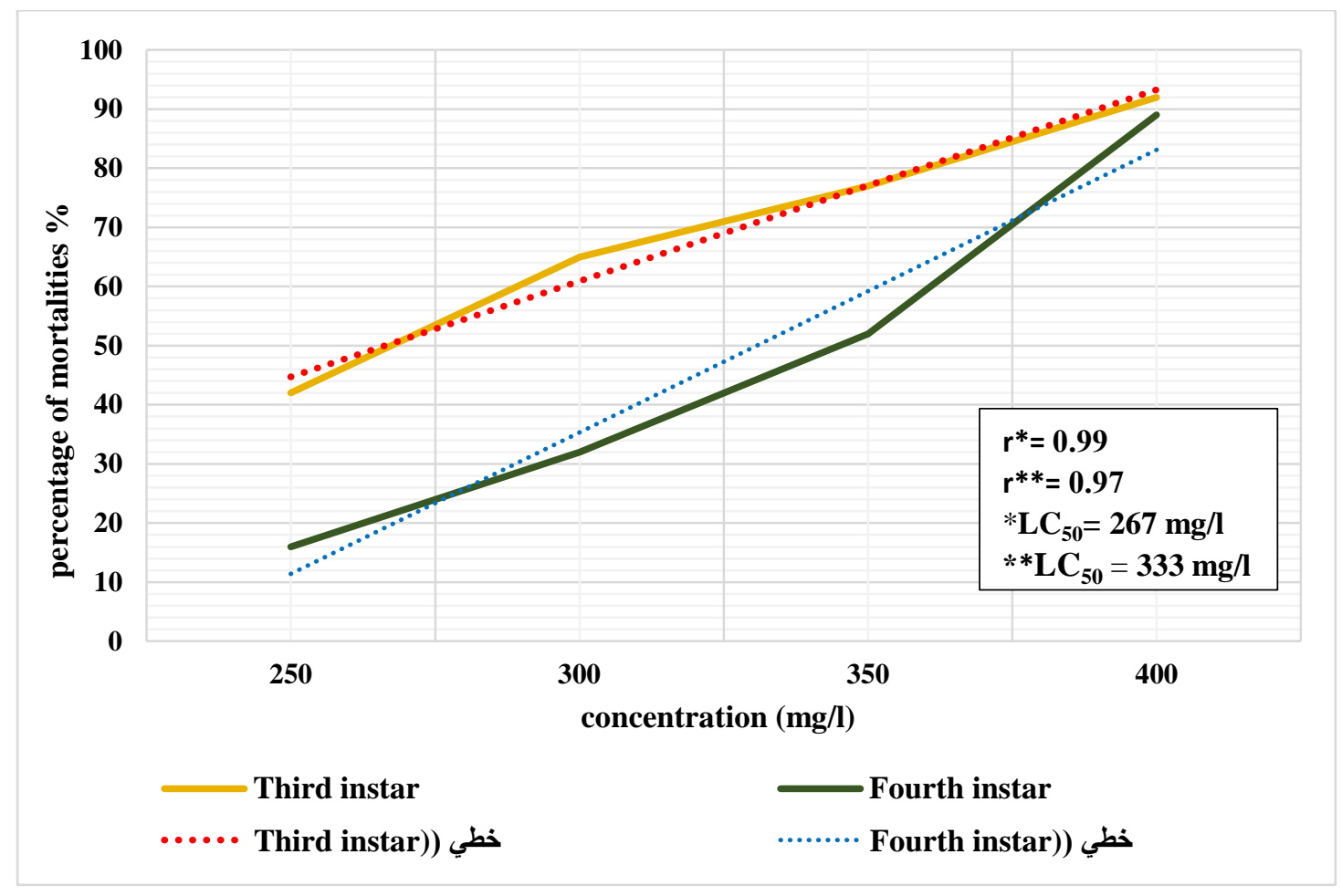

Figure (3) $\mathrm{LC}_{50}$ value for third and fourth instar of $C$. pipiens after 24 hours exposure to different concentration of cold water extract of $P$. crispum leaves.

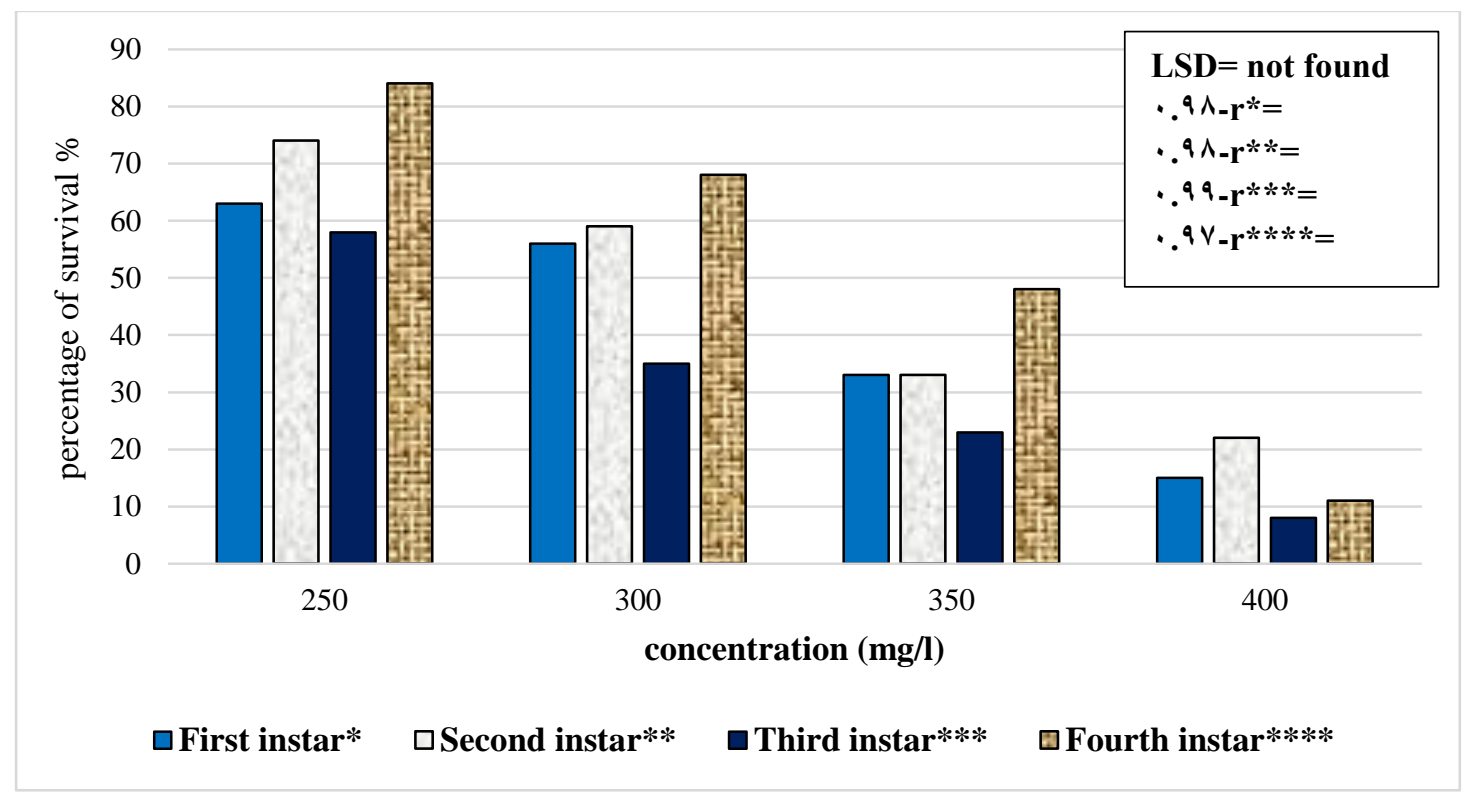

Figure (4) percentage of instars survival after 24 hours exposure to different concentration of cold water extract of $P$. crispum leaves. 


\section{7- References}

[1] N. O. Forstinus, N. E. Ikechukwu, M. P. Emenike and O. Osita, "Anopheline mosquitoes and the malaria scourge", Intern. J. of Mosq. Res., 2 (3): 200-207, 2015.

[2] S. N. Maodaa, A. A. Allam, J. Ajarem, M. A. Abdel- Maksoud, G. I. Al- Basher and Z. Y. Wang, "Effect of parsley (Petroselinum crispum, Apiaceae) juice against cadmium neurotoxicity in albino mice (Mus Musculus)". Behav. Brain. Funct., 12 (6): 1-16, 2016.

[3] G. Savage and L. Vanhanen, "Calcium and Oxalate Contents of Curly Leaf (Petroselinum crispum) and Flat Leaf (P. crispum var. neapolitanum) Parsley Cultivars”, Food and Nutr. Sci., 6, 1565-1570, 2015.

[4] F. H. Galal, A. Abu Elnasr, I. Abdallah, O. Zaki and A. E. M. Seufi, “Culex (Culex) Pipiens Mosquitoes Carry and Harbor Pathogenic Fungi during Their Developmental Stages”, Erciyes. Med. J., 39 (1): 1-6, 2017.

[5] J. A. C. Zequi and J. Lopes, "Development of the immature stages of Culex (Culex) saltanensis Dyar (Diptera, Culicidae) under laboratory conditions", Revista Brasileira de Entomologia, 56 (1): 106-110, 2012.

[6] S. Kitvatanachai, C. Apiwathnasorn, S. Leemingsawat, W. Wongwit and H. J. Overgaard, "Determination of lead toxicity in Culex quinquefasciatus mosquitoes in the laboratory". Sou. ea. Asi. J. of Trop. Medi. Pu. Heal., 36 (4), 2005.

[7] G. Okbatinsae and A. Haile, "In vitro studies of larvicidal effects of some plant extracts against Anopheles gambiae larvae (Diptera: Culicidae)”, J. of Med. Pl. Res., 11(4): 66-72, 2016.

[8] H. A. Soliman, N. A. Eltablawy and M. S. Hamed, "The ameliorative effect of Petroselinum crispum (parsley) on some diabetes complications”, J. of Medi. Plan. Stud., 3 (4): 92-100, 2015.

[9] W. S. Abbott, "A method of computing the effectiveness of an insecticide", J. Econ. Entomol., 18 (2): $265-$ $267,1925$.

[10] J. Devore, N. Farnum and J. Doi, “Applied Statistics for Engineers and Scientists" Cengage Learning, third edition, San Luis Obispo, California Polytechnic State University, Printed in the USA, pp: 656, 2014.

[11] D. S. A. Chaves, F. S. Frattani, M. Assafim, A. P. Almeida, R. B. Zingali and S. S. Costa, "Phenolic Chemical Composition of Petroselinum crispum Extract and Its Effect on Haemostasis", J. of Nat. Prod. Commun., 6 (7): 961-964, 2011.

[12] L. Mahmoodi, O. Valizadegan and V. Mahdavi, "Fumigant toxicity of Petroselinum crispum L. (Apiaceae) essential oil on Trialeurodes vaporariorum (Westwood) (Hemiptera: Aleyrodidae) adults under greenhouse conditions", J. of plant prot. Res., 54 (3): 294-299, 2014.

[13] R. Vokk, T. Lõugas, K. Mets and M. Kravets, "Dill (Anethum graveolens L.) and Parsley (Petroselinum crispum (Mill.) Fuss) from Estonia: Seasonal Differences in Essential Oil Composition”, Agrono. Res., 9 (2), 515520, 2011.

[14] H. Cetin, F. Erler and A. Yanikoglu, "Larvicidal activity of a botanical natural product, AkseBio2, against Culex pipiens". Fitoterapia, 75 (7-8): 724-728, 2004.

[15] L. Kothera, M. S. Godsey, M. S. Doyle and H. M. Savage, "Characterization of Culex pipiens Complex (Diptera: Culicidae) Populations in Colorado, USA Using Microsatellites", Plos one, 7 (10): e47602, doi:10.1371/journal pone, 0047602, 2012.

[16] A. Bouaziz, K. Amira, N. E. Djeghader, L. Aïssaoui and H. Boudjelida, "Impact of an insect growth regulator on the development and the reproduction potency of mosquito", J. of Entom. and Zoo. Stud. 5 (3): 1662-1667, 2017.

[17] U. Brammacharry and K. Paily, "Mode of action of mosquitocidal protein in the larvae and pupae of Culex. quinquefasciatus and biochemical and physiological changes in the mosquitoes exposed to protein", Int. J. Curr. Microbiol. App. Sci., 3 (11): 501-520, 2014.

[18] N. E. Djeghader, H. Boudjelida, A. Bouaziz and N. Soltani, "Biological effects of a benzoylphenylurea derivative (Novaluron) on larvae of Culex pipiens (Diptera: Culicidae)", Adva. in Appl. Sci. Rese., 4 (4):449-456, 2013.

[19] J. G. Scott, M. H. Yoshimizu and S. Kasai, "Pyrethroid resistance in Culex pipiens mosquitoes", Pest. Bioc. and Phys.,120: 68-76, 2015.

[20] J. Vézilier, A. Nicot, J. D. Lorgeril, S. Gandon and A. Rivero, "The impact of insecticide resistance on Culex pipiens Immunity”, Evolutionary Applications, 6: 497-509, 2013.

[21] A. Rivero, A. Magaud, A. Nicot and J. Zilier, "Energetic Cost of Insecticide Resistance in Culex pipiens Mosquitoes", J. Med. Entomol., 48 (3): 694-700, 2011. 


\title{
دراسة تأثير المستخلص المائي البارد لاوراق نبات المعدنوس \\ Culex pipiens على يرقات بعوض Petroselinum crispum
}

\author{
مي حميذ محمد الدهيمي \\ كلبة علوم البيئة / جامعة القاسم الخضر اء /بابل / العراق مئ \\ mayhameed85@yahoo.com
}

تهدف هذه الدراسة الى معرفة تاثير تراكيز مختلفة من المستخلص المائي البارد لاوراق نبات Petroselinum crispum على يرقات

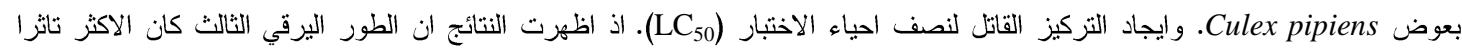

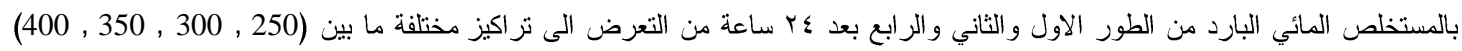

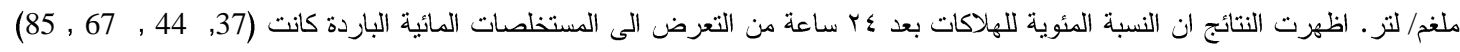

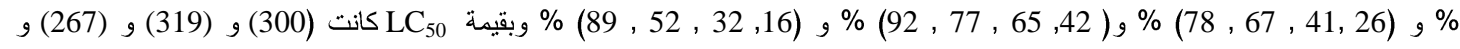

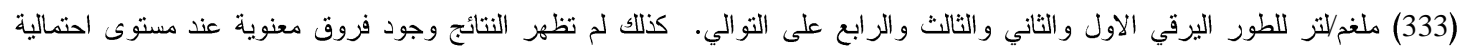

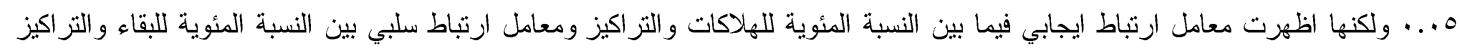

